Acta Veterinaria (Beograd), Vol. 63, No. 5-6, 499-511, 2013.

DOI: 10.2298/AVB1306499L

UDK: 581.35+619-097:591.11+611.663/591.572.4:616.699

\title{
THE INFLUENCE OF ANTISPERM Ig G AND Ig A ANTIBODIES FROM COWS SERA AND CERVICAL MUCUS ON BULL SPERM MOTILITY
}

\author{
LAZAREVIĆ $\mathrm{M}^{\star}$, SULJKANOVIĆ $\mathrm{A}^{* *}$, MICKOV LJ** ŠABANOVIĆ $\mathrm{M}^{\star * * *}$ \\ PAPRIKIĆ $\mathrm{N}^{* * * *}$ and MLINAR $\mathrm{S}^{* * * *}$ \\ *University of Belgrade, Faculty of Veterinary Medicine, Belgrade, Serbia \\ ${ }^{*}$ Veterinary Station Srebrenik, Federation $\mathrm{BH}$, \\ ${ }^{* * *}$ University of Cyrillus and Methodius Skopje, Veterinary Faculty, Skopje, Macedonia, \\ ****Veterinary Station, Živinice, Federation BH, \\ ${ }^{\star * \star * \star}$ Energetic Panacea Veterinary Clinic, Dubai, UE
}

(Received $4^{\text {th }}$ April 2013)

The aim of this study was to investigate the influence of antisperm $\lg G$ and $\lg A$ antibodies (ASA) from the sera and cervical mucus of cows on bulls sperm motility. A total of 64 cows was included in the study and samples of sera and cervical mucus were collected on the day of artificial insemination. Cows were of Busha breed or mix breed with Simmental. The presence of antisperm $\lg G$ and $\lg A$ antibodies was determined by indirect immunofluorescence method and according to these results, cows were dlvided in groups as follows: cows with high or low ASA titer in their sera and cows with high or Iow ASA titer in the cervical mucus. Influence of antisperm antibodies on sperm motility was further estimated by Computer Assisted Semen Analysis (CASA).

Results demonstrated a significant difference in the influence of antisperm antibodies depending on their origin and titer.

Key words: antisperm antibodies, computer assisted sperm analysis, cows, subfertility

\section{INTRODUCTION}

Repeat breading is still one of the most significant problems in the reproduction of dairy cows. It is usually defined as a lack of conception following three subsequent artificial inseminations (Al) with no obvious symptoms of genital tract disease. A repeat-breeder (RB) is a cow which shows a reduced probability of conception while all other factors are optimal (Casida, 1961) and thus require more attempts of Al to achieve pregnancy. If mated naturally, RB cows or heifers very often improve their reproductive results (Vukotić et al., 1982). The possible causes of this phenomenon are numerous and include delicate nutritional misbalance, subtle hormonal disturbances and possibly immunological mechanisms. It was 
postulated that enhanced immunological reactivity to sperm or semen extender antigens might be one of the reasons for RB (Park and Hunter, 1977).

In natural mating the immune response to sperm antigens usually does not occur due to the low sperm and seminal plasma constituents immunogenicity (Hogarth, 1982). Also, all body fluids important for fertilization (seminal plasma, cervical mucus, follicular and uterine fluid) exert immunosuppressive effects (Landers et al., 1994). In Al chances for immunization of females to sperm antigens are enhanced because seminal plasma is diluted several times, thus reducing its very strong immunosuppressive effects (Lazarević, 1991, Lazarević et al., 1992) and new antigens originating from semen extenders are added. We have documented (Lazarević et al., 2003, Jaćević and Lazarević, 2000, Jaćević, 1998) by sperm agglutination and indirect immunofluorescence method that bulls spermatozoa differ in antigenicity if different semen extenders are used for semen preparation in Al technology.

An understanding of the functions of the mucosal immune system in the female reproductive tract is essential for dealing with problems of infertility and sub-fertility. One of the major problems, in both human and animal reproduction, is sterility with no obvious symptoms (unexplained infertility) that can be caused by anti-sperm antibodies (ASA) in seminal plasma, cervical mucus, uterine fluid, follicular fluid or sera (Stern et al., 1992). The role of ASA in infertility and sub-fertility in mammalian species is still not clearly understood but it is well known that auto-immunization of the male and iso-immunization of the females with sperm cells can lead to a significant impairment of fertility (Wright 1980, Kim et al., 1999) . Interference of ASA with reproductive processes may occur by impairment of sperm migration through the cervix, uterus and oviduct and by blocking adherence of spermatozoa to the surface of the zona pellucida of the oocyte as postulated by Schumacher (1998). The same author stated that serum antibody levels do not always reflect levels of antibodies in the female genital tract secretions and that mucosal immunity may be operational mainly in the cervical compartment of the genital tract. Kim et al. (1999) demonstrated that experimentally generated bull anti-sperm antibodies significantly reduce fertilization in vitro. Much earlier, Wright (1980) described a negative influence of anti-sperm antibodies raised by intensive immunization of bulls on semen quality. This phenomenon was described for numerous laboratory animals as reviewed by Hogarth (1982). Bratanov et al. (1975) proved that sera containing anti-sperm antibodies from infertile cows and women with unexplained infertility inhibit acrosomal proteolitic activity in vitro and therefore possibly may affect fertilization. Maas et al., (1989) demonstrated a close correlation between a positive sperm antibody test and poor post-coital test results in infertile couples. These authors concluded that determination of ASA in the CM must be regarded as an improvement in the diagnostic procedure in human infertility. We have also reviewed the possible negative influence of anti-sperm antibodies on the reproduction processes (Jaćević and Lazarević, 2000). 
There is a strong evidence that in humans, sperm-mucus interactions can be affected by local ASA, especially of the Ig A class, both under in vitro and in vivo conditions However, the significance of ASA in the sera of infertile patients was not established, while those in seminal plasma or CM impaired the ability of sperm cells to penetrate CM (Eggert-Kruse et al., 1993). Check et al. (1991) demonstrated that the antifertility effect of ASA may be mainly the immobilization of sperm in the cervical mucus and thus intrauterine insemination may effectively correct the problem. The role of antisperm $\lg A$ antibodies is also documented in the investigations conducted by Clarke (1988) and Kremer and Jager (1992).

Investigations in veterinary medicine regarding the influence of antispermatozoal antibodies in CM on fertility rates are very few. The elevation of sperm-agglutinating antibodies titer in the cervical mucus and sera of artificially inseminated cows according to the number of attempts was clearly demonstrated by Jaćević (1998). In the technology of artificial insemination of cows the antigenic structure of sperm cells is changed due to the addition of different extenders, freezing and thawing procedures and reduction of seminal plasma volume. In addition, immunosuppressive activity of bull seminal plasma is significantly reduced during semen preparation for Al (Lazarević, 1991).

Computer Assisted Semen Analisis (CASA) is a relatively new method that enables a precise measurement of the sperm motility and other sperm characteristics both in human or animal semen samples. It has been also used to compare semen characteristics between different cattle breeds (Hoflack et al., 2007). Moreover, in veterinary medicine it was possible to study the influence of various extenders or extender supplements on the post-thaw motility, acrosome morphology and plasma membrane integrity by CASA (Hu et al., 2009). Recently CASA method was used for profiling boar semen samples (Didion, 2008). This method is very valuable in determining initial semen quality as well as changes during storage under different conditions (Tardif et al., 1997). By accumulating data by CASA it is now possible to investigate more accurately the relationship between sperm characteristics and fertility of males (Farrell et al., 1997).

In this study we investigated the presence of ASA in the sera and cervical mucus of artificially inseminated Simmental and mix breed cows and their influence on motility parameters of sperm cells originating from native or thawed bull semen.

\section{MATERIAL AND METHODS}

Sera sampling: Sera were collected from Simmental or Busha cross breed cows at Srebrenik and Živinice $(\mathrm{BIH})$ region, by jugular vein puncture on the day of artificial insemination. Sera were obtained following coagulation at room temperature and centrifugation at $3000 \mathrm{rpm}$ for $20 \mathrm{~min}$. All samples wer kept frozen at $-20^{\circ} \mathrm{C}$ pending analisis. The animals were divided in two groups 
according to the average value of ASA in sera or cervical mucus. All cows were previously inseminated with bull semen prepared for Al with egg-yolk extender.

Cervical mucus sampling: Prior to Al, CM samples were collected by placing a sterile sponge swab in the near vicinity of the external cervix end by sterile plastic catheter as described earlier (Lazarević et al., 2003). All samples were kept frozen at $-20^{\circ} \mathrm{C}$ until use.

Semen sampling: Semen samples were collected from four Simmental bulls by means of an artificial vagina in the Regional Center for Artificial Insemination. The semen had normal characteristics of motility, morphology and concentration and underwent the standard procedure of preparation for Al. Ejaculates were diluted with TRIS egg yolk extender at an average ratio of 1:10 and kept frozen at $-196^{\circ} \mathrm{C}$ before use.

Indirect immunofluorescence assay (IIF): The IIF assay was performed according to Noel et al. (1974). This procedure was described in details earlier (Lazarević et al., 2003). Basically, after thawing the 12 (3 from each of 4 bulls) medium French straws for Al $(0.25 \mathrm{~mL})$, sperm cells were washed twice by centrifugation procedure in pre wormed PBS $\left(\mathrm{pH} 7.2,37^{\circ} \mathrm{C}\right)$, resuspended by Vortex and used for smear preparations. On the dried sperm cell smears, $10 \mu \mathrm{L}$ of sera or $\mathrm{CM}$ sample (inactivated at $56^{\circ} \mathrm{C}$ for 20 minutes) was placed and incubated for 20 min at $37^{\circ} \mathrm{C}$ in a wet chamber. Following incubation, the slides were washed three times $(5 \mathrm{~min}$ ) in PBS and dried at room temperature. In the second step, $10 \mu \mathrm{L}$ of secondary FITC (fluorescein isothiocyanate) conjugated antibodies (anti-bovine Ig A, ICN, USA, Cat No 641 751) was placed on the slide and incubated again under the same conditions. Conjugation of anti Ig A antibodies with FITC (ICN, USA, Cat No F 4274) was performed according to The and Feltkamp (1970). After incubation, followed by the same washing procedure, the slides were kept in a dark and wet chamber until examined. As a positive control we used sera obtained by immunization of calves with content of straws prepared with TRIS egg yolk extender as described in detail elsewhere (Lazarevic et al., 2000). Calf sera obtained before immunization served as the negative control. Microscopic examination was performed on the NIKON EFD - 3 microscope with the B-2A filter at $1600 \mathrm{X}$ magnification. The appearance of fluorescence on the head, tail or neck of the sperm cell was considered as a positive result and the last dilution giving a positive reaction was taken into account. Titer values were expressed according to Sjurin et al., (1984) as $\log _{2} \mathrm{n}(1: 2=1,1: 4=2$ etc).

\section{Sperm motility asessment}

Basic parameters of the bulls sperm motility were determined by CASA method (Computer Assisted Semen Analyses). Analyses were performed in series of five sera or cervical mucus samples following $30 \mathrm{~min}$. incubation at $37^{\circ} \mathrm{C}$. We measured total sperm motility, progressive motility and velocity, tail movement amplitude and frequency by use of sperm-analyzer Hamilton - Thorn (HTM IVOS Version 2, No M 9368, USA) 
Prior to each group of five samples, same parameters were determined in negative control samples (inactivated serum of 3 months old calf). Results were calculated as a percent of the control values for a given group. Values obtained with negative controlled were considered as $100 \%$. Samples were further divided in two groups depending on the ASA titer (high or low titer) despite of the antibody class ( $\lg G$ or $\lg A)$. Sera samples with higher total titer value of ASA ( $\lg A$ and Ig $G$ together) then 1:16 and cervical mucus samples with titer above 1:64 were considered as high titer samples.

Statistical analyses were performed after calculating mean values and standard deviations. The significance of the differences between mean values was estimated by Student's t test.

\section{RESULTS}

The appearance of the control sample picture on the Hamilton-Thorn CASA analyzer is presented in Figure 1. Curved lines represent cells expressing progressive motility that was not altered by the presence of the control serum.

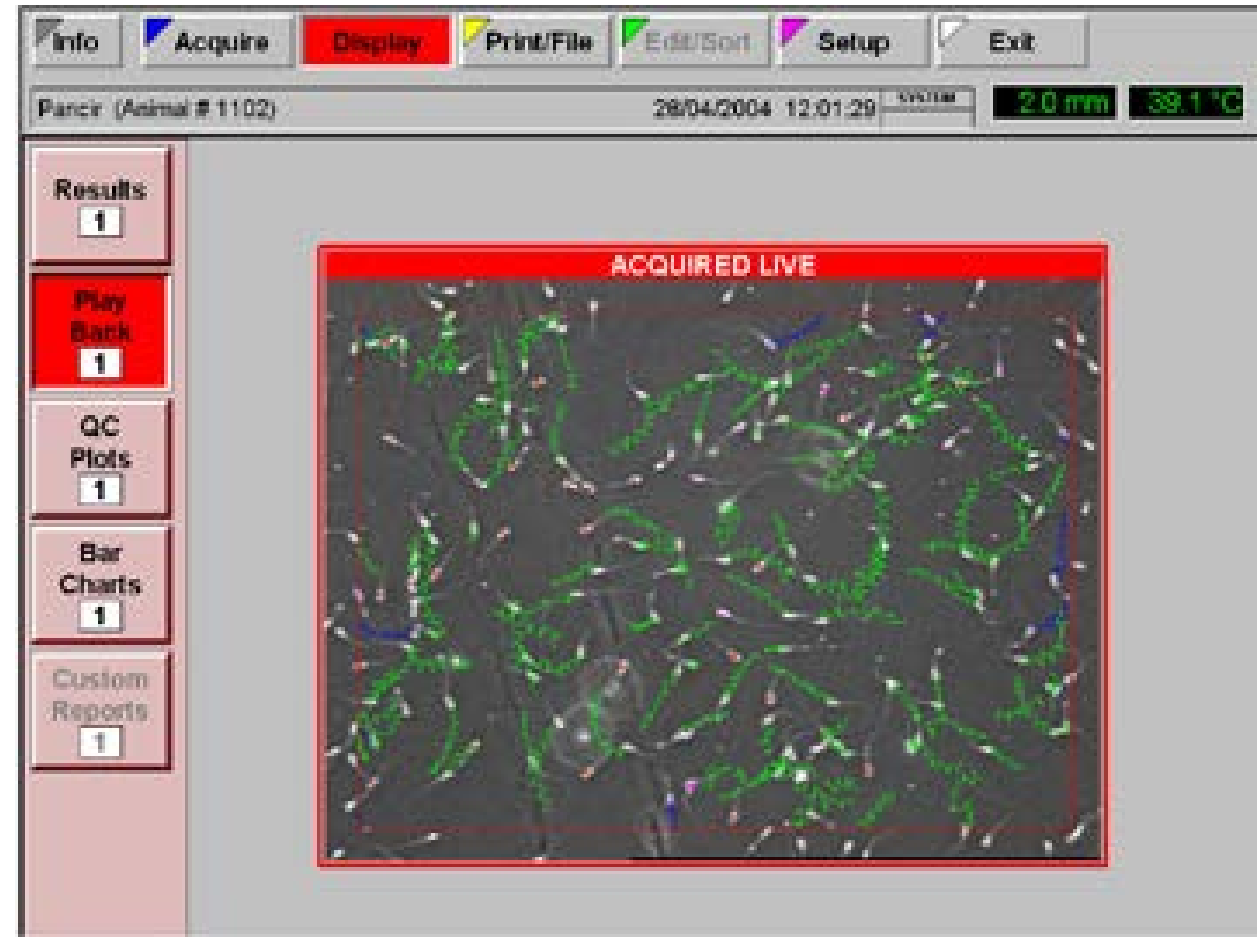

Figure 1. Control sample on CASA analyzer (curved lines represent cells expressing progressive motility) 
Figure 2. represents picture acquired from a cervical mucus sample containing a high titer of ASA. Only few sperm cells expressed progressive motility (curved lines).

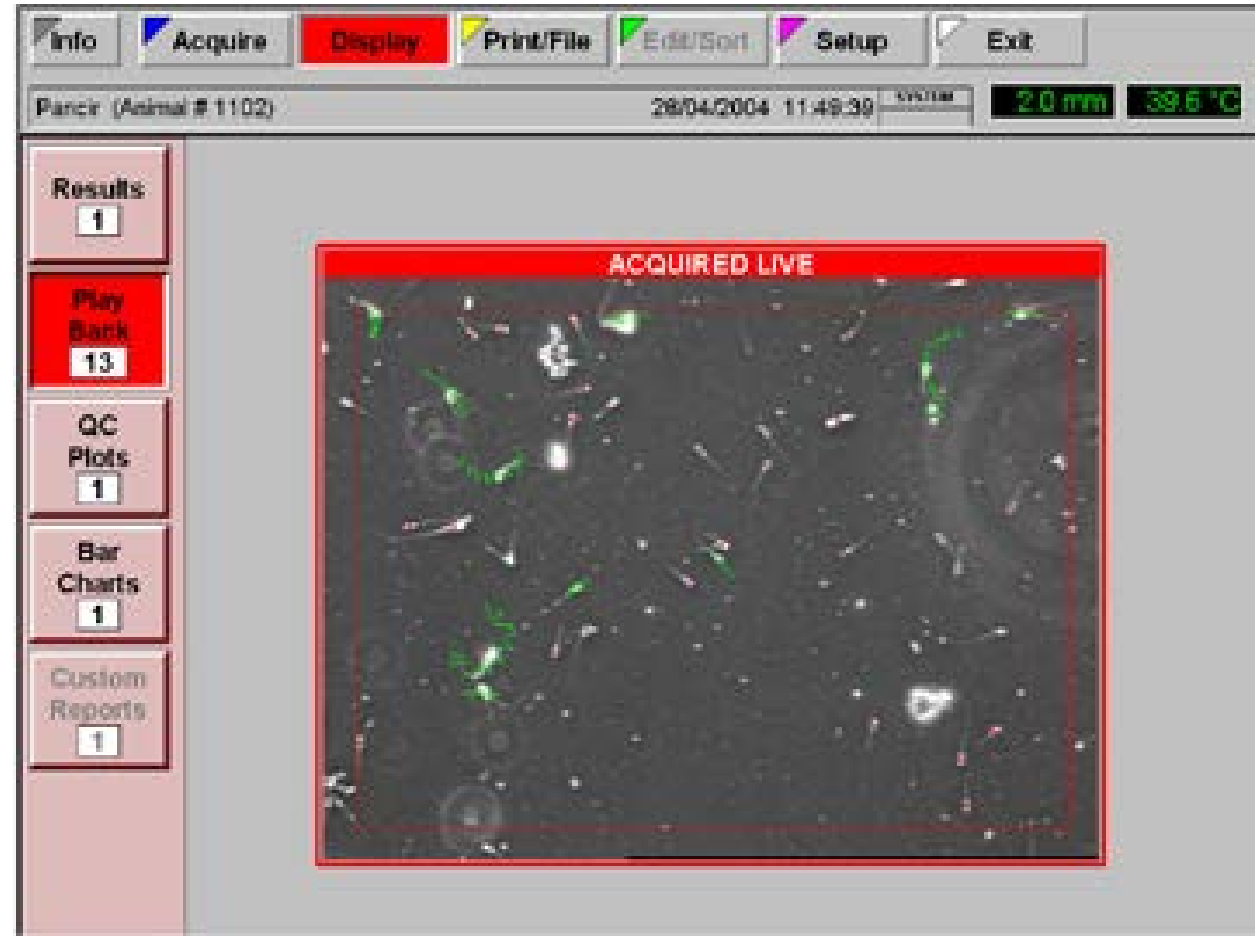

Figure 2. Cervical mucus sample with a high titer of ASA on CASA analyzer (curved lines represent cells expressing progressive motility)

As can be concluded from the data presented below (Table 1) total sperm motility was significantly decreased, both in the native and thawed sperm samples following incubation with sera containing high titers of ASA.

Table 1. Total sperm motility (\% of control value) depending on semen origin and ASA titer in the cow's blood sera

\begin{tabular}{|c|c|c|c|c|}
\hline & \multicolumn{3}{|c|}{ Blood sera } \\
\hline & \multicolumn{2}{|c|}{ Native semen } & \multicolumn{2}{c|}{ Thawed semen } \\
\hline & $\begin{array}{c}\text { Low ASA titer } \\
\mathrm{n}=11\end{array}$ & $\begin{array}{c}\text { High ASA titer } \\
\mathrm{n}=15\end{array}$ & $\begin{array}{c}\text { Low ASA titer } \\
\mathrm{n}=10\end{array}$ & $\begin{array}{c}\text { High ASA titer } \\
\mathrm{n}=13\end{array}$ \\
\hline $\mathrm{X}$ & $45.36 \pm 23.86 \%$ & $37.21 \pm 20.18 \%$ & $49.48 \pm 21.15 \%$ & $40.90 \pm 22.61 \%$ \\
\hline
\end{tabular}

Progressive sperm motility was also lower in the native semen samples incubated with sera samples containing the high ASA titer (Table 2). These 
differences were not significant in samples incubated under the same conditions when thawed semen was used for the test. Moreover, thawed semen had much lower progressive motility than native despite the ASA titer.

Table 2. Progressive sperm motility (\% of control value) depending on the semen origin and ASA titer in the cow's blood sera

\begin{tabular}{|c|c|c|c|c|}
\hline & \multicolumn{4}{|c|}{ Blood sera } \\
\hline & \multicolumn{2}{|c|}{ Native semen } & \multicolumn{2}{c|}{ Thawed semen } \\
\hline & $\begin{array}{c}\text { Low ASA titer } \\
\mathrm{n}=11\end{array}$ & $\begin{array}{c}\text { High ASA titer } \\
\mathrm{n}=15\end{array}$ & $\begin{array}{c}\text { Low ASA titer } \\
\mathrm{n}=10\end{array}$ & $\begin{array}{c}\text { High ASA titer } \\
\mathrm{n}=13\end{array}$ \\
\hline $\mathrm{X}$ & $45.24 \pm 26.25$ & $35.53 \pm 22.88$ & $26.25 \pm 8.60$ & $25.59 \pm 15.08$ \\
\hline
\end{tabular}

Table 3. presents data obtained by estimating progressive sperm velocity (\% regarding control) according to the semen origin and ASA titer in the blood sera of cows. Values were lower when thawed semen was used but no statistically significant differences were recorded .between samples containing high and low ASA titer.

Table 3. Progressive sperm velocity (\% of control value) depending on ASA titer and semen origin in cow's sera

\begin{tabular}{|c|c|c|c|c|}
\hline & \multicolumn{3}{|c|}{ Blood sera } \\
\hline & \multicolumn{2}{|c|}{ Native semen } & \multicolumn{2}{c|}{ Native semen } \\
\hline & $\begin{array}{c}\text { Low ASA titer } \\
\mathrm{n}=11\end{array}$ & $\begin{array}{c}\text { High ASA titer } \\
\mathrm{n}=15\end{array}$ & $\begin{array}{c}\text { Low ASA titer } \\
\mathrm{n}=10\end{array}$ & $\begin{array}{c}\text { High ASA titer } \\
\mathrm{n}=13\end{array}$ \\
\hline $\mathrm{X} \pm \mathrm{SD}$ & $102.02 \pm 23.85$ & $98.31 \pm 18.94$ & $81.38 \pm 24.20$ & $76.61 \pm 19.27$ \\
\hline
\end{tabular}

It is also evident (Table 4) that total sperm motility was lower when samples of the cervical mucus with high ASA titer were analyzed despite the semen origin (native or thawed). Differences were higher when thawed semen was used for analysis.

Table 4. Total sperm motility (\% of control value) depending on the semen origin and ASA titer in cow's cervical mucus

\begin{tabular}{|c|c|c|c|c|}
\hline & \multicolumn{3}{|c|}{ Cervical mucus } \\
\hline & \multicolumn{2}{|c|}{ Native semen } & \multicolumn{2}{c|}{ Thawed semen } \\
\hline & $\begin{array}{c}\text { Low ASA titer } \\
\mathrm{n}=16\end{array}$ & $\begin{array}{c}\text { High ASA titer } \\
\mathrm{n}=20\end{array}$ & $\begin{array}{c}\text { Low ASA titer } \\
\mathrm{n}=16\end{array}$ & $\begin{array}{c}\text { High ASA titer } \\
\mathrm{n}=22\end{array}$ \\
\hline $\mathrm{X}$ & $69.01 \pm 24.82$ & $49.17 \pm 33.29$ & $50.56 \pm 27.77$ & $30.72 \pm 24.72$ \\
\hline
\end{tabular}

Progressive sperm motility expressed the same pattern of changes as total motility. Motility was the smallest when thawed semen was incubated with cervical mucus samples containing high ASA titer (Table 5). 
Table 5. Progressive sperm motility ( $\%$ of control value) depending on ASA titer and semen origin in cows cervical mucus

\begin{tabular}{|c|c|c|c|c|}
\hline & \multicolumn{4}{|c|}{ Cervical mucus } \\
\hline & \multicolumn{2}{|c|}{ Native semen } & \multicolumn{2}{c|}{ Thawed semen } \\
\hline & $\begin{array}{c}\text { Low ASA titer } \\
\mathrm{n}=16\end{array}$ & $\begin{array}{c}\text { High ASA titer } \\
\mathrm{n}=20\end{array}$ & $\begin{array}{c}\text { Low ASA titer } \\
\mathrm{n}=16\end{array}$ & $\begin{array}{c}\text { High ASA titer } \\
\mathrm{n}=22\end{array}$ \\
\hline $\mathrm{X} \pm \mathrm{SD}$ & $75.66 \pm 34.59$ & $49.59 \pm 34.33$ & $34.16 \pm 20.75$ & $19.72 \pm 14.74$ \\
\hline
\end{tabular}

Like for the last two parameters, progressive sperm velocity (Table 6) was decreased when samples containing high ASA titers were analyzed with both native and thawed semen.

Table 6. Progressive sperm velocity ( $\%$ of control value) depending on ASA titer and semen origin in cow's cervical mucus

\begin{tabular}{|c|c|c|c|c|}
\hline & \multicolumn{3}{|c|}{ Cervical mucus } \\
\hline & \multicolumn{2}{|c|}{ Native semen } & \multicolumn{2}{c|}{ Native semen } \\
\hline & $\begin{array}{c}\text { Low ASA titer } \\
\mathrm{n}=16\end{array}$ & $\begin{array}{c}\text { Low ASA titer } \\
\mathrm{n}=16\end{array}$ & $\begin{array}{c}\text { Low ASA titer } \\
\mathrm{n}=16\end{array}$ & $\begin{array}{c}\text { High ASA titer } \\
\mathrm{n}=22\end{array}$ \\
\hline $\mathrm{X} \pm \mathrm{SD}$ & $86.71 \pm 23.83$ & $74.28 \pm 42.27$ & $78.93 \pm 16.41$ & $66.10 \pm 18.64$ \\
\hline
\end{tabular}

As differences in the mean values for tail frequency movement and amplitude were not statistically different they are not presented here. The only exception was tail movement frequency when sera samples with low and high ASA titer were incubated with native or thawed semen (Table 8).

Tables 7 and 8 contain results of the statistical analisis of differences between mean values of the estimated semen motility parameters.

Table 7. Statistical differences between sperm motility parameters regarding ASA titer values (low vs high titer)

\begin{tabular}{|l|c|c|}
\hline & $\begin{array}{c}\text { Cervical mucus } \\
\text { Low vs high ASA titer }\end{array}$ & $\begin{array}{c}\text { Blood sera } \\
\text { Low vs high ASA titer }\end{array}$ \\
\hline & \multicolumn{2}{|c|}{ Native semen } \\
\hline Total motility & $\mathrm{P}<0.05$ & $\mathrm{NS}$ \\
\hline Progressive motility & $\mathrm{P}<0.05$ & $\mathrm{NS}$ \\
\hline Progressive velocity & $\mathrm{NS}$ & $\mathrm{NS}$ \\
\hline Tail amplitude & $\mathrm{NS}$ & $\mathrm{NS}$ \\
\hline Frequency & $\mathrm{NS}$ & $\mathrm{NS}$ \\
\hline & & $\mathrm{NS}$ \\
\hline Total motility & $\mathrm{P}<0.05$ & $\mathrm{NS}$ \\
\hline Progressive motility & $\mathrm{P}<0.05$ & $\mathrm{NS}$ \\
\hline Progressive velocity & $\mathrm{P}<0.05$ & $\mathrm{NS}$ \\
\hline Tail amplitude & $\mathrm{NS}$ & semen \\
\hline Frequency & $\mathrm{NS}$ & \\
\hline
\end{tabular}

NS - not significant 
Total and progressive motility estimation of the native semen revealed that these paramers were lower following incubation with cervical mucus samples containing a high ASA titer. This was also evident when thawed samen was used and values were even lower. Moreover, with thawed semen, progressive sperm velocity was also significantly decresed. Differences between tail amplitudes and frequency were not significant. Following incubation of sera samples with low and high ASA titer motility parameter values were not significantly different.

Statistical significance of differences in parameters of sperm motility depending on the semen origin (native or thawed) following incubation with sera and cervical mucus samples with low and high ASA titer are presented in Table 8.

Table 8. Statistical differences between sperm motility parameters regarding origin of the semen (native vs thawed semen)

\begin{tabular}{|c|c|c|}
\hline & $\begin{array}{c}\text { Cervical mucus } \\
\text { Native vs thawed semen }\end{array}$ & $\begin{array}{c}\text { Blood sera } \\
\text { Native vs thawed semen }\end{array}$ \\
\hline & \multicolumn{2}{|c|}{ High ASA titer } \\
\hline Total motility & $\mathrm{NS}$ & $\mathrm{NS}$ \\
\hline Progressive motility & $\mathrm{P}<0.01$ & $\mathrm{P}<0.05$ \\
\hline Progressive velocity & $\mathrm{NS}$ & $\mathrm{P}<0.01$ \\
\hline Tail amplitude & $\mathrm{NS}$ & $\mathrm{NS}$ \\
\hline Frequency & $\mathrm{NS}$ & $\mathrm{N}$ \\
\hline & & $\mathrm{N}$ \\
\hline Total motility & $\mathrm{P}<0.05$ & $\mathrm{~N}$ \\
\hline Progressive motility & $\mathrm{P}<0.01$ & $\mathrm{NSA}$ titer \\
\hline Progressive velocity & $\mathrm{NS}$ & $\mathrm{P}<0.01$ \\
\hline Tail amplitude & $\mathrm{NS}$ & $\mathrm{NS}$ \\
\hline Frequency & $\mathrm{NS}$ & $\mathrm{N}$ \\
\hline
\end{tabular}

NS - not significant

Regarding ASA origin (cervical mucus or sera) progressive sperm motility was significantly lower when sperm cells from thawed straws for Al were used for the test with both low and high ASA titer of cervical mucus samples. Values were much lower in samples with high ASA titer. In samples with high ASA titer total motility was also significantly decreased. Moreover, in sera samples with high ASA titer progressive motility and progressive velocity were decreased when thawed semen was used for the test. Frequency of tail movements was also lower and interestingly this phenomenon was observed in sera samples with Iow ASA titer. 


\section{DISCUSSION}

We were able to notice that, apart from significant differences in sperm motility parameters, variation intervals and coefficients of variation were relatively high (data not presented here). This emphases individual variability of the observed sperm motility characteristics and in some cases led to the lack of statistical significance..

In 2005 Milovanović at al. reported that the lenghth of open days period was significantly incresed in cows with high ASA titer both in sera and cervicl mucus. Milovanović et al., (2007) later on stated that the critical titre value of the antisperm Ig A antibodies from cervical mucus in cows is $1: 64$, as of $A l$ in the last oestrus and number of Al per pregnancy were significanly higher in cows that had IgA ASA titer above this value.

Rapid changes in intensive milk production during the last decades are dramatic and milk yield is constantly rising as a consequence of genetic selection, improved nutrition and management. However, it seems that cows with higher milk production have more reproductive problems. The most important causes of this phenomenon are estrus control and silent estrus, metabolic influences of lactation on reproduction and early embryonic death (Lucy, 2001). Recently, it was clearly demonstrated that insufficient reproductive results in high-yielding milking cows, are closely related to negative energy balance (NEB) emerging from metabolic and hormonal changes due to extreme milk production. Therefore, a "price" for high productivity might be decreased fertility induced by hormonal disbalance. The conception rate following first $\mathrm{Al}$ is decreased from previous $60 \%$ to $40-50 \%$ and even $30 \%$ in some herds (Butler and Smith, 1989). Hormones that might have a dominant role are $\mathrm{LH}$, because its pulsations are decreased during NEB, and endogene opioids influencing pituitary gland functions (Butler and Smith, 1989). Balendran et al. (2008) investigated progesterone concentrations and conception rate in cows of different age. Conception rate following first Al was $67.9 \%$ in heifers, $42.9 \%$ in primiparous cows, $20.0 \%$ in cows with two calvings and only $11.9 \%$ in older cows (3-4 calvings). Surprisingly the progesterone concentration was not significantly different in the groups enlisted above. There are some data confirming a correlation between body condition score (BCS) and fertility. According to Pryce et al. (2001), cows with lower BCS after calving are more susceptable to reproductive disorders. This confirms that cows in NEB have reduced chances for conception and exactly in that period they are being inseminated, very often with no positive outcome. As it was proven in numerous studies, ASA titer increases with the age and total number of Al attempts, it is likely that cows might be isoimmunised with antigens originated from semen and/or extender partly because of seminal plasma lack. Immunological subfertility raised in this way may represent an additional difficulty towards succesful conception. It is our strong opinion that this hypothesis is realistic but so far, there are no reliable data to support it. 
We are able to conclude that levels of the ASA are increasing with age and total number of Al attempts and that ASA in cervical mucus reduce sperm motility. Moreover, NEB reduces the chances for fertilization and a novel approach to this problem is needed to overcome the present situation.

\section{ACKNOWLEDGEMENT:}

This work was funded by Serbian Ministry for Science and Technological Development, Project No. III 46002, 2011-2014, "Molecular genetic and ecophysiological researches on the protection of autochthonous animal resources, sustaining domestic animals' welfare, health and reproduction, and safe food production"

Address for correspondence:

Dr Miodrag Lazarevic, professor

Faculty of Veterinary Medicine

University of Belgrade

Bul. oslobodjenja 18

11000 Belgrade, Serbia

E-mail: lazarevicm@vet.bg.ac.rs

\section{REFERENCES}

1. Baledran A, Gordon M, Pretheeban T, Singh R, Perera R, Rajamahedran R, 2008, Decreased fertility with increasing parity in lactating dairy cows, J Can Anim Sci, 88, 425-8.

2. Bratanov K, Tornyov A, Hristova-Koleva M, 1975, Studies on the immunoglobulins in secretion of the female reproductive tract, III Int Symp Immunol Reprod, Varna, Abstracts, 68.

3. Casida EL, 1961, Present status of the repeat breeder cow problem, J Dairy Sci, 44, 2323-9.

4. Butler RW, Smith $D R$, 1989, Interrelationships between energy balance and postpartum reproductive function in dairy cattle, $J$ Dairy Sci, 72, $767-83$.

5. Check JH, Adelson HG, Bollendorf A, 1991, Effect of antisperm antibodies on computerized semen analysis, Arch Androl, 27, 61-3.

6. Clarke GN, 1988, Immunoglobuline class and regional specificity of antispermatozoal antibodies blocking cervical mucus by human spermatozoa, Am J Reprod Immunol Microbiol, 16, 135-8.

7. Didion $A B, 2008$, Computer - assisted semen analyses and its utility for profiling boar semen samples, Theriogenology, 70, 1374-6

8. Eggert-Kruse W, Bockhem-Hellwig S, Doll A, Rohr G, Tilgen W, Runnebaum B, 1993, Antisperm antibodies in cervical mucus in an unselected subfertile population, Hum Reprod, 8, 1025-31.

9. Farrell BP, Presicce AG, Brocket CC, Foote HR, 1997, Quantification of bull sperm characteristics measured by computer-assisted sperm analysis (CASA) and relationship to fertility, Theriogenology, 49, 871-9.

10. Hogarth JP, 1982, Immunological aspects of mammalian reproduction, Blackie, Glasgow \& London, 50-83.

11. Hu JH, Li QW, Chen YL, Hang YL, Jia YH, Wang LQ et al., 2009, Effects of addition of vitamin B12 to the extender on post-thaw motility, acrosome morphology, and plasma membrane integrity in bull semen, Turk J Vet Anim Sci, 33, 5, 379-84.

12. Jaćević $V, 1998$, Spermaglutinini u krvnom serumu i cervikalnoj sluzi junica i krava sa različitim indeksom osemenjavanja, Magistarski rad, Fakultet veterinarske medicine, Beograd.

13. Jaćević $V$, Lazarević $M$. 2000, Antitela protiv spermatozoida i njihov značaj u patogenezi neplodnosti žena, Vojnosanit Pregl, 57, 3, 331-8.

14. Kim CA, Parrish JJ, Momont HW, Lunn DP, 1999, Effects of experimentally generated bull antisperm antibodies on in vitro fertilization, Biol Reprod, 60, 1285-91. 
15. Kremer J, Jager S, 1992, The significance of antisperm antibodies for sperm-cervical mucus interaction, Hum Reprod, 7, 781-4.

16. Landers DL, Bronson AD, Pavia SC, Stites PD, 1997, Reproductive immunology, Ch. 17, 20015, In: Basic and Clinical immunology, Lange Medical Pubiications,

17. Lazarević $M, 1991$, Ispitivanje imunomodulatornih svojstava semene plazme bika u in vitro uslovima. Doktorska disertacija, Veterinarski fakultet, Beograd.

18. Lazarević M, Ejdus L, Rosić G, 1992, The influence of bovine seminal plasma, egg yolk extender and their mixture on bovine lymphocyte blastogenesis, Acta Vet Belgrade, 42, 4, 227-37.

19. Lazarević M, Milanović S, Kirovski D, Milovanović A, 2003, Antisperm antibodies of the Ig A class in the cervical mucus and sera of artificially inseminated cows, Acta Vet Belgrade, $53,5-6,311-9$.

20. Lazarević M, Rodić S, Ostojić J, Jakovljević G, Jovičin M, 2000, Primena indirektne imunofluorescence u određivanju antigenskih karakteristika spermatozoida bika. XIV savetovanje agronoma, veterinara i tehnologa, Aranđelovac, Zbornik naučnih radova, $6,401-9$.

21. Lucy CM, 2001, Reproductive loss in high-producing dairy cattle - where it will end? J Dairy Sci, 84, 1277-93.

22. Maas DH, Timm G, Mesrogli M, Degenhardt F, 1989, Spermatozoal antibodies in cervical mucus and in the luminal fluid of the uterus in sterile patients, Geburshilfe Frauenheilkd, $49,3,248-51$.

23. Milovanović A, Lazarević M, Milanović S, Kirovski D, Jovičin M, 2005, Open days period and antispermatozoal antibodies in artificially inseminated cows, Acta Vet Belgrade, 55, 5-6, 449-60.

24. Milovanović A, Lazarević M, Kirovski D, Jovičin M, Barna T, 2005, Antispermalna antitela u cervikalnoj sluzi junica i krava i njihov uticaj na reproduktivne pokazatelje, Zbornik radov 5. Simpozijuma “ Ishrana, reprodukcija i zaštita zdravlja goveda”,Banja Kanjiža, 4-7 juli, 189-95.

25. Noel RR, Hjort T, Rumke p, Harper JKM, Vyazov O, 1974, Techniques for detection of iso and auto-antibodies to human spermatozoa, Clin Exp Immunol, 23, 175-99.

26. Park YW, Hunter AG, 1977, Effect of repeated insemination with egg-yolk semen extender on fertility in cattle, J Dairy Sci, 60, 1645 - 9.

27. Pryce EJ, Coffey PM, Simm G, 2001, The relationship between body condition score and reproductive performance, J Dairy Sci, 84, 1508-15.

28. Schumacher GF, 1988, Immunology of spermatozoa and cervical mucus, Hum Reprod, 3,3, 289-300.

29. Sjurin N, Belorusova VR, Fomina VM, 1984, Veterinarnaja virusologija, Kolos, Moskva.

30. Stern JE, Dixon PM, Manganeillo PD, Brinck-Johnsen T, 1992, Anti-sperm antibodies in women: variability in antibody levels in serum, mucus and peritoneal fluid, Fertil Steril, 60, 1-6.

31. Tardif $L A$, Farrell BP, Trouern-Trend V, Foote HR, 1997, Computer/assisted sperm analyses for assessing initial semen quality and changes during storage at $5 \mathrm{oC}, J$ Dairy Sci, 80, 1606-12.

32. The TH, Feltkamp TWE, 1970, Conjugation of fluorescein isothiocyanate to antibodies, I Experiments on the conditions of conjugation, Immunology, 18, 868-73.

33. Vukotić M, Pavlović M, Stojić V, Petrović S, Kuzmanov D, Predojević M, 1982, Some evidence on immunological resistance of heifers to artificial insemination, In Proc 4th Int Symp Immunol Reprod, Varna, P 125.

34. Wright PJ, 1980, Serum sperm agglutinins and semen quality in the bull, Aust Vet J, 56, 10-3. 


\title{
UTICAJ ANTISPERMALNIH ANTITELA Ig G I Ig A KLASE POREKLOM IZ SERUMA I CERVIKALNE SLUZI KRAVA NA POKRETLJIVOST SPERMATOZOIDA
}

\author{
LAZAREVIĆ M, SULJKANOVIĆ A, MICKOV LJ, ŠABANOVIĆ M \\ PAPRIKIĆ N I MLINAR S
}

\begin{abstract}
SADRŽAJ
Osnovni cilj ovih istraživanja je bio da se ispita uticaj antitela $\lg \mathrm{G}$ i Ig A klase protiv antigena spermatozoida (ASA) iz krvnog seruma i cervikalne sluzi krava na pokretljivost spermatozoida bika. Studijom je bilo obuhvaćeno 64 plotkinje a uzorci seruma i cervikalne sluzi su prikupljani na dan veštačkog osemenjavanja. Krave su bile rase buša ili melezi buše sa simentalcem. Titar antitela $\lg \mathrm{G}$ i lg A klase je određivan metodom indirektne imunofluorescence i na osnovu tih rezultata krave su bile podeljene u sledeće grupe: plotkinje sa visokim i niskim titrom ASA u krvnom serumu i plotkinje sa visokim i niskim titrom ASA u cervikalnoj sluzi. Uticaj ASA na pokretlivost spermatozoida je zatim određivan kompjuterskom analizom (Computer Assisted Semen Analisis - CASA).

Dobijeni rezultati ukazuju značajne razlike u uticaju ASA na pokretljivost spermatozoida u zavisnosti od njihovog porekla i titra.
\end{abstract}

